\title{
The Roman Family as Institution and Metaphor After the Civil Wars
}

\author{
Andrew Gallia ${ }^{*}$
}

\begin{abstract}
A mother had a son who wore the blue and another who wore the gray. Father and son have fought on either side. The dearest ties of blood and friendship stand suddenly separated and arraigned in deadliest enmity, and yet Nature will assert her sway at last; and should Death intervene to lay one low, as passionate, tender tears are shed as if the war had been a dream.
\end{abstract}

— A. Hunter, Johnny Reb and Billy Yank (1905: 177-8)

\section{Grieving Matrons in Lucan's Civil War}

The second book of Lucan's De Bello Civile provides an apt introduction to the ways in which the trauma of civil war was refracted through the lens of family in Roman culture. The book opens with the terrible omens of war (manifesta belli / signa, 2.1-2) that reveal the gods' anger at the outbreak of the conflict between Caesar and Pompey. Lucan focalizes the religious dread that these signs provoke in Rome through the experience of the city's matrons, whose introduction into the narrative is mediated by an evocative simile:

tum questus tenuere suos, magnusque per omnes erravit sine voce dolor. sic funere primo

\footnotetext{
* Published in J. Klooster and I. N.I. Kuin (eds.), After the Crisis: Remembrance, Reanchoring and Recovery in Ancient Greece and Rome. (London: Bloomsbury, 2020).
} 
attonitae tacuere domus, cum corpora nondum

conclamata iacent, nec mater crine soluto

exigit ad saevos famularum bracchia planctus,

sed cum membra premit fugiente rigentia vita

voltusque exanimes oculosque in morte minaces;

necdum est ille dolor, nec iam metus: incubat amens

miraturque malum. cultus matrona priores

deposuit, maestaeque tenent delubra catervae.

Then their complaining they suppressed, and deep voiceless

grief pervaded all. Just so at the moment of death

the stunned house falls silent - not yet is the body

laid out and bewailed, not yet does the mother with loosened hair

impel the slave-girls' arms to savage breast-beating-

the moment when she hugs limbs stiffening as life flees,

the inanimate features, eyes swimming in death.

Fear is past and grief not yet arrived: distraught, she bends over him, stunned by her loss. Their former finery the Roman matrons

laid aside and in grieving bands they fill the temples...

(Luc., B.C. 2.20-29, transl. Braund)

In her commentary on this passage, Elaine Fantham describes how "the simile here uses private experience as both symbol of the collective grief and omen of future 
bereavement" (1992: 83). The stunned silence that prevails at the onset of the public crisis is equated with the initial moments of emotional turmoil for a bereaved mother. This connection is underscored by the blurry rhetorical boundaries of the literary figure itself, as the matrona reemerges as part of the main narrative in line 28 (after the simile has concluded) to put on mourning attire and fill the temples with grief.

The invocation of matronly bereavement in both private and public contexts serves to underscore the dual ways in which family matters are integral to the larger thematic concerns of Lucan's poem. ${ }^{1}$ On the one hand, the family as a constitutive unit of Roman society is structured according to the same affective and moral principles that govern the community as a whole, such that a mother's grief can stand in for that of the Republic itself. On the other hand, the poet's move from public to private and back again in this passage also calls attention to the interdependency between these two realms in a more immediate way, as it suggests that Roman men and women would experience the horrors of the impending civil war as both a domestic and a civic crisis simultaneously. The public sorrow of a community riven by civil war is also the private sorrow of its citizens, and vice versa.

The two-sided nature of the connection between civic and domestic realms (res publica and res privata) reappears later in the same book of Lucan's epic, when the reader is confronted with the unconventional nature of Cato's family arrangements as he and Brutus contemplate how to respond to the looming conflict. In a startling display of

\footnotetext{
${ }^{1}$ The issue of family in the epic is too pervasive and too complex for me to provide an adequate treatment here. Note especially the apparition of Julia's ghost at the beginning of Book 3, which concludes with a curse, abscidis frustra ferro tua pignora: bellum / te faciet ciuile meum (3.33-34: 'it is pointless for you to sever these pledges with arms: civil war will make you mine'). On the importance of the bond between Pompey and Caesar as gener and socer, see below, also Ambühl, this volume.
} 
his commitment to the principles of Stoicism, Cato had divorced his wife Marcia so that she could be married to his friend Q. Hortensius and bear him legitimate children, only to remarry her upon Hortensius' death, in 49 BCE. (Plut., Cato Min. 25.4-5, 52, Fehrle 1983: 201-203). In the context of Lucan's narrative, the sudden reappearance of the recently widowed Marcia at Cato's doorstep threatens to upend, or at least complicate, the defense of partisan engagement with which the sage had been winning over the younger Brutus (Sannicardo 2007: 89). Cato, who had just finished analogizing his own devotion to the doomed Republic to that of a father grieving at a child's funeral pyre (2.297-301), is confronted by the mother of his children, hair and clothes disheveled by mourning and grimy from the ash of an actual pyre, as she asks to be restored to her prior status as the wife of Cato (2.326-45).

Marcia is nevertheless aware of where such a private and personal appeal fits within the wider framework of Cato's public responsibilities, and she therefore proposes a different kind of marriage from the ones she had known before:

non me laetorum sociam rebusque secundis accipis: in curas venio partemque laborum. da mihi castra sequi: cur tuta in pace relinquar et sit civili propior Cornelia bello?

'As no partner in prosperity or joy do you receive me: into anxieties I come, to share your struggles. Allow me to accompany the camp. Why should I be left in peace and safety? 
Why should Cornelia be closer to civil war?'

(Luc., B.C. 2.346-9, transl. Braund)

Having fulfilled the principal obligation of a Roman wife to bear offspring in not one, but two households, Marcia now seeks a different role for herself as wife, that of the devoted companion who will share in her husband's hardships. This rhetoric proves persuasive, and such is the marriage into which she is welcomed. The ceremony with which the couple resumed their vows was a private and solemn affair, with none of the festive elements typical of a Roman wedding. The renewed union is not consummated, as Cato denies himself even licit amor ('love') in his mourning for the fate of the world (379-80: iusto quoque robur amori / restitit.).

These developments mark another way in which the family could be impacted by the trauma of civil war. The poet goes on to praise the unique features of Cato's home life as evidence of his rigid sense of honor and his devotion to the public good above all else, but it is also apparent that this radically unique (if ethically superior) form of marriage was only intelligible, if not conceivable, within the surrounding context of political crisis and civil war (Harich 1990, cf. Panoussi 2007: 120-4). Women do not usually have the opportunity to follow their husbands into harm's way in times of peace, and there is no need to eschew the conjugal joys of marriage unless the freedom of mankind is facing mortal peril. The fact that such a drastic reimagining of the marriage bond was possible (if only for someone like Cato) also suggests a more dynamic relationship between individual families and this surrounding context of civil war. Not only do families suffer when the polity is in crisis, their suffering also sometimes leads to the reaffirmation and 
rearticulation of bonds within the family, thereby filling the void left by the disintegration of analogous bonds in the public realm.

These insights into the impact of civil war on the family reflect deeply established tendencies in Roman discourses about crisis. ${ }^{2}$ Rather than trace these strands back to the myths of the Sabine women (cf. Miles 1992) or Coriolanus' relationship with his mother Veturia (cf. Beltrami 1998: 123-174), this chapter surveys the historical literature of the Imperial period to explore how the experience of civil war shaped Roman ideas about the family, both as an institution and as a metaphor for other kinds of social relationships, in the context of generalized social collapse. As we have already seen in Lucan, the family was deeply enmeshed in Roman narratives of civil war. The material here examined reveals two contrary but related structures of thought, which may be labeled, faute de mieux, as 'optimistic' and 'pessimistic'. The first of these perspectives celebrates the family as a bulwark against the storm of civic disintegration, in which bonds of loyalty are tested and yet still endure. The latter perspective, meanwhile, emphasizes the breakdown of traditional family roles, which is understood as both a consequence and cause of the wider dissolution of public morality. After the crisis was over, official efforts to reanchor a Roman concept of the family, as reflected in the Augustan family legislation, can be seen as responding to both of these perspectives simultaneously.

\section{Exceptional Cases}

\footnotetext{
${ }^{2}$ The connection between family and civic crisis is in fact a common one, which can be traced with benefit through other periods of history. Narratives about the American Civil War in particular have consistently been framed according to the terms of Lincoln's (antebellum) invocation of Matthew 12:25 ("A house divided against itself cannot stand," 1989: 426). See, e.g., the epigraph to this chapter.
} 
Marcia's willingness to share in Cato's anxieties and troubles point to the potential importance of the family as a source of resilience in the face of crisis. As the reference to Pompey's wife Cornelia indicates (Luc. 2.349, cf. 5.722-815, 8.33-108), this display of familial devotion was not an isolated occurrence in the Roman experience of civil war. Although it may seem unsurprising from a modern sociological perspective that individuals faced with the dissolution of shared patriotism and political harmony in a civil war would fall back to rely more heavily on the support of the family unit (McCubbin and Patterson 1982), such stories were in fact regarded as extraordinary according to their conventional framing in the Greco-Roman historical tradition. For example, Thucydides' descriptions of the effects of the plague in Athens (2.52-3) and especially the Corcyrean stasis (3.82-4) present breakdowns in public morality as pervading all aspects of life within a city. In Corcyra, factional loyalties (to heairikon) supplanted those of family (to xungenes), as the capacity to trust in human connections "was confirmed not so much by divine law as by the communication of guilt" (3.82.6: אaì

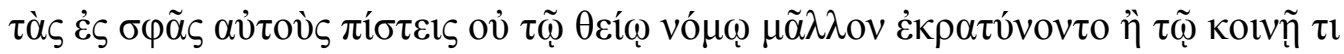
$\pi \alpha \rho \alpha v o \mu \tilde{\eta} \sigma \alpha$, transl. Hobbes). In contrast to such totalizing narratives, Roman Imperial historians also sought to highlight the exceptions.

We may begin with Tacitus' Histories, which open with the author's reflections on the challenges of writing contemporary history under the Principate and an assessment of his own qualifications for the task. He explains that, while there is nothing to prevent him from writing about the present, he intends to leave the reigns of Nerva and Trajan for his old age and begin instead with the Flavian era and the civil wars of $69 \mathrm{CE}$. In contrast to the 'richer and safer material' of his own day, Tacitus specifies that the era covered in 
the present work represented a veritable horror show of calamities, involving natural disasters and devastating battles (in both civil and foreign wars), not to mention the reign of a tyrannical emperor, a kind of low-grade civil war, in which the fabric of Roman society was further rent apart by informers and terror (1.1.4-2.3). This history, while bleak, would not be unrelentingly so, however, as Tacitus goes on to clarify:

non tamen adeo virtutum sterile saeculum ut non et bona exempla prodiderit. comitatae profugos liberos matres, secutae maritos in exilia coniuges; propinqui audentes, constantes generi, contumax etiam adversus tormenta servorum fides.

Yet this age was not so barren of virtue that it did not also produce good examples. Mothers accompanied their fleeing children, wives followed husbands into exile, relatives were daring, sons-in-law steadfast, the fidelity of slaves was defiant even against torture.

(Hist. 1.3.1)

Tacitus' concession to the virtue of such figures is still tinged with pessimism, of course, and in the context of his narrative the bona exempla of familial loyalty provide little respite from the pervasive tragic quality of the narrative as a whole (Ash 2007: 5-8).

Perhaps the most famous (and unsettling) case is the story of the Julii Mansueti, a Spanish father and son serving in opposing legions who came together at the second battle of Cremona, but only recognized one another after the son had mortally wounded his father. The grief-stricken son begs forgiveness for this unwitting parricide, protesting 
that 'the crime was a communal one, for what stake does one soldier have in such a multitude of civil arms?' (3.25.2: publicum id facinus; et unum militem quotam civilium armorum partem?). He then returns to his proper role as a dutiful son, fulfilling his private obligation by burying his father's corpse (3.25.3: supremo erga parentem officio fungi). This scene of battlefield recognition, a kind of grotesque reworking of the meeting between Diomedes and Glaucon in Homer (Il. 6.120 ff.), is of course a well-known topos in the historiography of civil war (cf. Sisenna, FRH 26 F 132), but this likely made it more effective as an aspect of popular lore as well. ${ }^{3}$

Another event that may have its basis in a story that Tacitus would have heard of first-hand concerns the raiding of Otho's forces along the coast of Liguria. The mother of Tacitus' father-in-law, who owned property in the region, was also killed in the course of these raids (Agr. 7). Perhaps this connection explains how the historian came to hear of the 'brilliant example' (praeclaro exemplo) of an anonymous Ligurian woman who refused to reveal the whereabouts of her son, even under torture (Hist. 2.13). Her reply to the marauding soldiers emphasizes the primal nature of the obligation to her child: 'pointing to her womb, she said that he was hiding there' (uterum ostendens latere respondit). She presents her body as a physical manifestation of the maternal bond: just as she had sheltered her son during pregnancy, so would she continue to protect him with

\footnotetext{
${ }^{3}$ Tacitus explicitly invokes the authority of Vipstanus Messala when introducing the episode into his account of the battle, which I take as an indication that the historian felt the testimony of an eyewitness was necessary for a story that seemed too good to be true in its juxtaposition of public and private concerns to create a metonymic encapsulation of the horrors of civil war (both moral and real) through their impact on an individual family. Compare Syme 1958: 177.
} 
her womb. ${ }^{4}$ Such a pointed and dramatic story of constantia served to frame the trauma of civil war and the violent pressure it brought to bear on the immutable bonds of family as impinging upon the very laws of nature.

The Ligurian women's refusal to reveal her son's hiding place is reminiscent of a somewhat happier story preserved by Valerius Maximus in a brief chapter of the Memorable Deeds and Sayings on the loyalty of wives to their husbands (de fide uxorum erga viros), in which a certain Turia shielded her husband Lucretius from the triumviral proscriptions by hiding him in the attic of her bedroom (6.7.2, cf. App., B.Civ. 4.44). Some scholars have sought to link this Turia to the unnamed dedicatee of a fragmentary inscription in which a husband praises his wife, among other things, for rescuing him during these same proscriptions (Mommsen 1905: 415-417, cf. Gordon 1977). The husband recalls, "how ... I was saved by your counsel, how you did not suffer me to court disaster so rashly and unthinkingly, and by planning with more discretion prepared a secure hiding-place for me" (CIL 6.41062 = ILS 8393 2, 16-18: ut ... tuis consiliis cons[er]vatus sim? ut neque audac[i]us experiri casus | temere passa sis et mod[es]tiora cogitanti fida receptacula pararis). The association remains uncertain, however, and the assumption that this was the only woman called upon to protect her husband in these uncertain times is certainly unjustified (Osgood 2014: 117-125).

Cassius Dio also records a similar story about Tanusia, who concealed her husband T. Vinius in a chest at a freedman's house until she could appeal to Octavian for clemency (47.7.4, cf. App., B.Civ. 4.44, Suet., Aug. 27.2). Acilius' wife sacrificed her

\footnotetext{
${ }^{4}$ Compare Agrippina's invocation of her motherhood through a similar gesture to the centurion sent to kill her in Ann. 14.8.5: protendens uterum 'ventrem feri' exclamavit; Ash 2007: 114.
} 
jewelry, just as the dedicatee of the inscription did, to purchase safe passage out of Italy for her husband (App., B.Civ. 4.39). The wife of Ligarius, whose deeds are recorded by Appian (B.Civ. 4.23), also attempted to hide her husband from the dangers of the proscriptions, but was unfortunately betrayed by a slave. After her husband was killed, she took her devotion further, demanding that the triumvirs condemn her as well for having sheltered a named enemy of the state. When they declined to punish her out of respect for her philandria, she starved herself to death instead as a mark of supreme devotion to her condemned husband.

The list of examples could be extended. Appian provides an extensive catalogue of such cases, using stories of faithful wives, sons, and slaves to counterbalance accounts of those who had betrayed their husbands, parents, or masters during the proscriptions (B.Civ. 4.39-51, Gowing 1992: 259-262). He claims to have selected these anecdotes carefully, presenting only those that were 'most surprising and most likely to amaze'

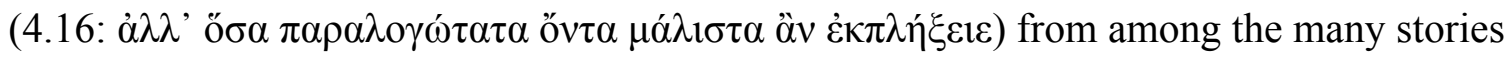
that made up an extensive Roman literature on the subject. We might doubt whether Appian in fact bothered to consult multiple sources for his inventory (cf. Gabba 1956: 223-224), but his observations about the popularity of this theme in Imperial historiography rings true. As with the contemporary (and not unrelated) fashion for recounting the 'death scenes' (exitus, Plin., Ep. 5.5.3) of famous men, these accounts of families under stress accomplished what Lisa Hau has described as "moralising through pathos" (2016: 86, also in this volume). Because of the emotional impact that such stories imparted to the narrative, the framing of civil wars and proscriptions in terms of the extraordinary hardships imposed on the intimate and affective bonds of family served to 
highlight the essential nature of these crises. Like Tacitus, Appian makes sure to emphasize the difference between this bygone era of violent upheaval and the happiness

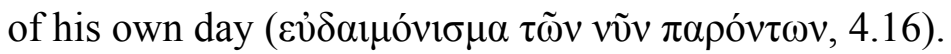

Within this broader discourse, the subset of 'optimistic' stories of familial devotion represent something more than a type of silver lining for Roman historians to impose upon the stormy and depressing narrative of civil war, however. Indeed, the final outcome of events was not always a cheerful one. But as the Laudatio inscription perhaps more than any other piece of evidence makes clear, these tales also give genuine insight into how many Romans would have framed their own experience of crisis. When the security of civil society was stripped away, the integrity of the family was tested in ways that had profound implications for individual survival (Hinard 1990). For the men and women who lived through the trauma of civil war and proscriptions, these experiences will have deeply transformed their sense of the value of the family and of its place in Roman society. Additionally, as a bond that could survive and even strengthen in the face of the collapse of political institutions, the familial devotion represented in these exemplary narratives also offered an anchor upon which to affix hopes for the restoration of a virtuous civil society in the aftermath of these crises. If the family could survive, so too could the res publica. ${ }^{5}$

This latter effort involved a form of metaphorical projection common in the history of Roman concepts, whereby the moral values that operate within one sphere of social life are treated as scalable, such that, for example, the pietas of a child to a parent (itself derived from the reverence of a mortal to the gods) could be expanded to

\footnotetext{
${ }^{5}$ Compare here Alexander's arguments (2012) about collective responses to cultural trauma, discussed by Eckert in this volume.
} 
encompass the attitude of the subject toward the state (Roller 2001: 217-18, 249, cf. Schröder 2012). The overlapping domains of such concepts led to the family being seen as a microcosm of the community at large and was used to establish frameworks whereby familial relationships could stand in for other social bonds. In this regard, much has been written about the title of pater patriae ('father of the fatherland'), and the explicit fashioning of the savior of the state according to the role of a father (Alföldi 1971, Severy 2003: 158-160). Consideration of the experiences of Roman families in civil war helps us better to understand how this title became a powerful symbol for the likes of Cicero, Julius Caesar, Augustus, and others who worked to rebuild after the crises that brought them to power.

As revealing as the self-representation of the dictator or emperor as a father-figure is, however, it is also perhaps too narrow a framework for assessing the impact of the familial experience of civil war, as it fails to account for an important dimension of so many of the above-cited cases - namely, the active role that women played, as mothers, daughters, wives and sisters, in preserving the integrity of their families during the crisis of civil war. While essential to the interpretation of these exempla, the gendered quality of these stories also ultimately calls attention to the fundamental asymmetry of the public and private spheres as normally conceived of in Roman culture. The extraordinary importance of women within the household, when held up against their conventional exclusion from the political realm, complicates any attempt to draw upon these scenes of familial devotion as a model for political reintegration.

Upon closer inspection, it is clear that a large part of what made these stories of mothers' and wives' (often anonymously commemorated) dedication to the interests of 
their sons and husbands exemplary is the paradoxical nature of the actions they undertook to protect their male kin. Rather than stay within the dependent position circumscribed for them within the household, these women were prompted by the crisis of civil war to take on roles traditionally reserved for men. This boundary-crossing is perhaps most evident in the long narrative of the elogium-inscription, where the husband praises his wife inter alia for providing for him financially (CIL 4.41062 2, 1: [varia et amplissima subsi]dia fugae meae praesitisti), for her ingenuity and good advice $(2,4$ : [nostrorum deceptis a]dversarium custodiis, 2, 17: tuis consiliis cons[er]vatus sim), and for her courage in publicly appealing to Lepidus to seek permission for his safe return $(2,30$ : quid hac virtute efficaciu[s]). These narratives are thus as much a challenge to the conventional sexual order as a reassertion of the primary value of family within Roman society. As Josiah Osgood summarizes in his exemplary study of the Laudatio,

Civil war was a defining experience for her, testing her in ways that she otherwise might not have been. Her achievements were most conspicuous then, and along with the achievements of other women, including Augustus' wife Livia, led to lasting changes in how women might comport themselves in public.

(Osgood 2014: 150)

From the perspective of the author of our inscription, his wife's resourcefulness in taking on challenges that ordinarily were reserved for men prompts intense admiration and devotion. His view of women's capabilities (or at least that of his own wife) as well as his attitude toward the bond of marriage has therefore been 're-anchored' to a new standard 
that would have been different in significant respects from what typically prevailed among men of his class.

\section{The Burden of the mos maiorum}

This was not, unfortunately, the final word on the subject. Against this point of view, we must also acknowledge that there were other powerful assumptions about gender roles within the family that continued to shape how such acts of heroism might be perceived. A woman who behaved like a man, even in the interest of her husband, was liable to be seen as a threat to the social order. Fulvia's conduct in the Perusine war, as characterized by Cassius Dio (48.3-14, esp. 48.10.4), is an extreme and therefore perhaps sufficient example of how a publicly engaged wife could be viewed as a dangerous virago, dressing up in military attire and consumed with her own power over the men around her (Osgood 2006: 160). While over-the-top in its invective extremity, this image nevertheless serves to illustrate the anxieties aroused in a patriarchal society by women who took advantage of the opportunities for political agency such as those afforded them in times of crisis and civil war. For those Roman men who did not directly benefit from the lifesaving acts in question, it was perhaps easier to respond to these episodes of transgression with horror than to celebrate them with gratitude and respect.

In light of the hostile characterization of Fulvia's actions on behalf of her husband's interests in Italy, it is clear that one might also draw a very different set of conclusions about the relationship between the family and Roman society more broadly in the context of civil war. For those predisposed to see women's participation in the public realm as categorically dangerous and unsettling, it was possible to view the 
prominence of strong women during the civil wars as yet another cause of, rather than a resilient response to, the breakdown in the broader social order. By reversing the chain of causation in this way, the crisis playing out in the political realm became the manifestation of a deeper crisis in the ancestral tradition, through which both the state and the traditional bonds of family were undone.

This more reactionary way of thinking about the family in the context of civil war would find encouragement from another type of narrative, in which family members betrayed rather than protected one another. Appian's account of the proscriptions is rich in this material as well, and it is notable that he follows the exemplary story of Ligarius' wife (who starved herself after failing to keep her husband hidden from the bountyhunters) with that of another unnamed woman, who not only arranged for her husband Septimius to be added to the proscription list, but also kept him at her house under the pretense of protecting him so that the executioners might take him more easily (B.Civ. 4.23). The emotional devastation that this type of disloyalty inflicted upon a defenseless husband comes through most dramatically in the case of Salassus, who feared betrayal by the slave he had sent to inform his wife where he was hiding. Salassus had climbed up on the housetop to look for signs of trouble, when 'seeing not the porter, but his wife leading

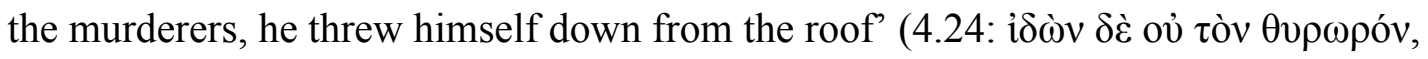

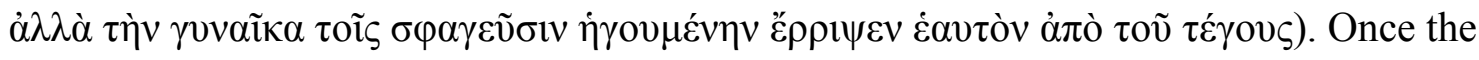
protection of familial bonds is stripped away, no hope remains.

Such monstrous behavior was not limited to the women within the family, of course. Tacitus likewise relates a story of outright fratricide, in which instead of being overcome by grief or horror (as the younger Mansuetus had been at the death of his 
father), the soldier who killed his brother had the audacity to request a special reward from his commanders (Hist. 3.51). ${ }^{6}$ Appian also records the story of the proscribed Thuranius, who had hoped that his son might use his influence with Antony to appeal for his life, only to discover that this son had already denounced him (B.Civ. 4.18). The most notorious connection between the breakdown of the family and the proscriptions involved the triumvirs themselves, however: Antony had placed his uncle L. Caesar on the lists, and Lepidus proscribed his own brother Paullus. As Cassius Dio comments:

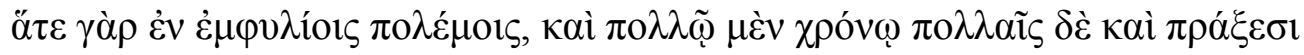

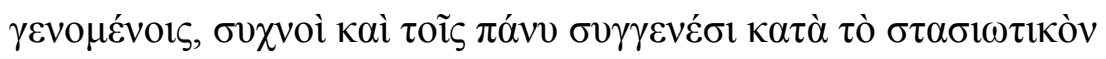
$\pi \rho о \sigma \varepsilon \kappa \varepsilon \kappa \rho о \cup ́ \kappa \varepsilon \sigma \alpha \nu$

For in internecine warfare, which involve much time and many events, many have come into conflict even with their own kin according to the principles of factionalism

(Dio, 47.6.2, cf. App., B.Civ. 3.37)

Thucydides' comments on the Corcyrean stasis and the all-pervasive corruption that accompanies civil strife had not lost their relevance. The roots of the crisis still extended into the institution of the family itself.

\footnotetext{
${ }^{6}$ Tacitus goes on to compare this soldier's shamelessness with the fiercer paenitentia recorded in Sisenna's account of the Marian civil wars, in which a soldier killed himself after realizing that he had committed a similar crime.
} 


\section{After the Crisis}

In the aftermath of civil war, the Romans had ready access to two radically different perspectives on the family: one which saw it as an institution in crisis just like every other institution suffering from the collapse of the ancient moral order, and another, more positive view, in which the family still endured as the final refuge against this collapse and a potential source of hope in a darkening world. Both of these perspectives reflected the realities of the ways in which the family had been forced to adapt under the strain of external crisis, particularly the increasing reliance on female relations who proved themselves capable of acting independently and exerting influence beyond the boundaries of the household. For some, this breach of traditional gender norms represented a disaster. The intervention of male relatives through institutions such as patria potestas (paternal authority) and tutela (male guardianship) had long been regarded as necessary checks against female mischief (Dixon 1984). For others, however, these developments represented an opportunity to revitalize the institution of marriage as a nurturing partnership founded on mutual affection and respect (cf. Veyne 1978).

This dual, or perhaps schizophrenic, narrative would seem to offer two very different starting points against which to reconstitute the larger social order in the aftermath of civil war. I think we can see these contradictions play out in the package of legislation often referred to as 'the Augustan marriage laws' (Treggiari 1991: 60-80, 277291, Galinsky 1996: 128-133). These laws were in fact a part of a more encompassing program of social legislation passed in the late 20's and early teens BCE, as part of the run-up to the declaration of a 'new age' with the Ludi Saeculares in 17 BCE. As Beth Severy explains: 
By criminalizing adultery, encouraging marriage and childrearing, and regulating everything from seating in the theater to the private display of wealth, these new laws cast Augustus as a savior of the state in the context of Roman morality, thus adding to his status as a military and political restorer of the res publica.

(Severy 2003: 50)

This was how Augustus himself characterizes these accomplishments in a familiar passage of his Res Gestae, in which he celebrates the restoration of 'many ancestral exempla that were already being erased' and the creation of 'new examples for posterity to follow' (RG 8: legibus novi[s] $m[$ e auctore l]atis $m[$ ulta e $]$ xempla maiorum exolescentia iam ex nostro [saecul]o red[uxi et ip $]$ se multarum re[rum exe $]$ mpla imitanda post[eris tradidi]). The ideological purpose of these laws was to promote the renewal of the social order by enacting a restoration of values that were imagined as lost.

Ostensibly, these laws represented an attempt to correct the moral collapse within the family that the long era of crisis and civil war had laid bare. Adultery was criminalized, with penalties both for promiscuous women and for men who violated the sanctity of the marital bond (Suet., Aug. 34, McGinn 2003: 140-215). At the same time, marriage was encouraged, along with the traditional moral vision of this institution as an instrument for reproducing the civic community through the production and raising of children (Dio 56.1.2-10.3, Treggiari 1991: 66-80). The importance of the family as a basic unity of the social order was also reinforced by means of regulations prohibiting intermarriage across certain social barriers (Treggiari 1991: 61-66). 
In placing the family at the center of his program of moral reform, Augustus would appear to be siding with those who saw the breakdown of that institution as a cause of the crises that needed to be confronted in order to recover from civil war. And yet, there is also a reflection of the more 'optimistic' vision of the family in the system of incentives through which portions of this legal program were meant to operate. The ius liberorum was a set of legal privileges bestowed upon couples who produced a sufficient number of children in the context of their marriage, which included, for matrons, the ability to inherit sums in excess of 100,000 HS (Cass. Dio, 56.10.2) and the right to conduct business without the intervention of a male guardian (Gaius, Inst. 1.145). The laws thus confirmed a new, more positive vision of women's ability to act independently in the interests of the family, while also redirecting the substance of their familial devotion from the sorts of good offices that many had been called upon to perform during the civil wars to the peacetime task of reproduction. ${ }^{7}$

\section{The Imperial family}

As domestic roles were being reconstituted and reconceptualized in this way, other changes were also taking place in the political structure of the respublica, of course. The overlap between this transformation and the Augustan reinvention of the family inevitably fostered an entirely new way of thinking about the connection between the family and the political community, in which the family of the princeps himself took

\footnotetext{
${ }^{7}$ To suggest another modern analogy, the situation is evocative of the evolution of gender roles in the United States following World War II, in which women's increased participation in the labor force (born of necessity as part of the mobilization for war) continued in the face of a renewed emphasis on domesticity and the demands of motherhood: Hartmann 1982: 77-95, cf. May 2008.
} 
center stage. The genesis of this new concept is outlined in another anecdote from Cassius Dio:

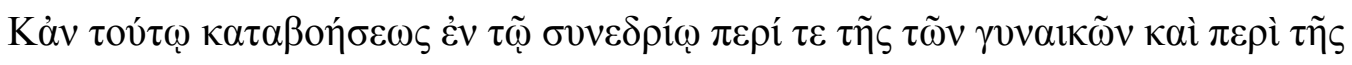

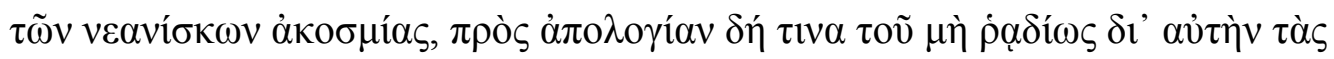

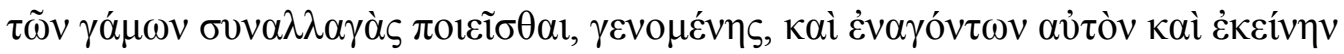

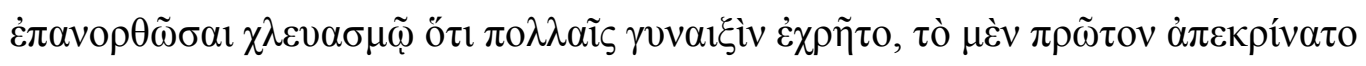

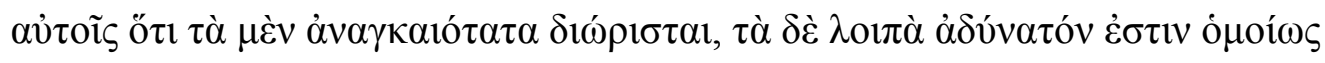

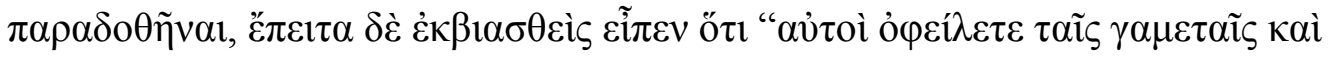

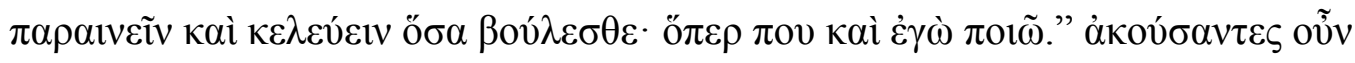

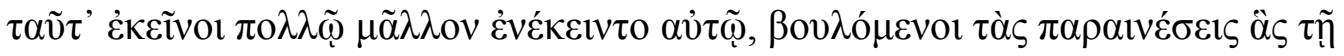

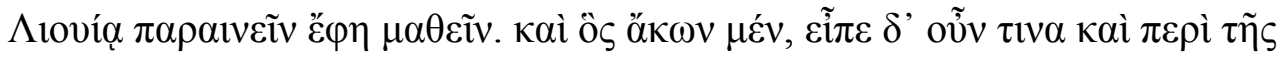

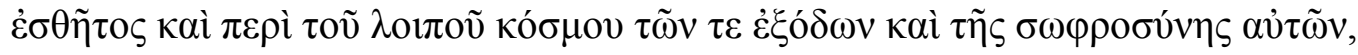

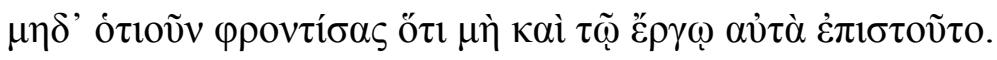

Meanwhile a clamor arose in the senate over the disorderly conduct of the women and of the young men, this being alleged as a reason for their reluctance to enter into the marriage relation; and when they urged him to remedy this abuse also, with ironical allusions to his own intimacy with many women, he at first replied that the most necessary restrictions had been laid down and that anything further could not possibly be regulated by decree in similar fashion. Then, when he was driven into a corner, he said: "You yourselves ought to admonish and command your wives as you wish; that is what I do." When they heard that, they plied him 
with questions all the more, wishing to learn what the admonitions were which he professed to give Livia. He accordingly, though with reluctance, made a few remarks about women's dress and their other adornment, about their going out and their modest behaviour, not in the least concerned that his actions did not lend credence to his words.

(Dio, 54.16.3-5, transl. Cary)

By placing so much emphasis on the reconstitution of the family as the basic unit of Roman society, Augustus invited more intensive scrutiny of his own activities as a paterfamilias. Not all of the attention would have been welcome, as the reference to Augustus' youthful peccadilloes suggests. The unusual circumstances of his marriage to Livia remained a source of potential embarrassment (Flory 1988), but the supposed misdeeds of their daughter brought the most grief, however, as Augustus felt compelled to denounce her in a detailed letter that was read out before to the senate (Suet., Aug. 65.2, Fantham 2006: 81-88).

With the introduction of autocracy, the family of the emperor became a public institution. This merging of the domestic and the political under a system of dynastic monarchy found particular expression in the extraordinary position of authority attained by the empress Livia (Purcell 1986). Although the anonymous wife of the Laudatio inscription would have been ineligible for the privileges of ius liberum because of the couple's inability to have children (CIL 6.41062 2, 42-50), Livia received these honors through an exceptional grant, despite the fact that she was the mother of only two sons (Dio, 55.2.6). Like Augustus' sister Octavia, she was also able to dedicate public 
buildings in her own name (Ov., Fast. 6.637-648). With the accession of Tiberius, Livia Augusta continued to accrue new honors as the mother of the reigning emperor and priestess of her deified husband's cult (Dio, 56.46.1, Severy 2003: 210-211). Her eventual deification, like that of other female members of the Imperial house, reflects (on an extraordinarily magnified scale) the changing nature of the Roman family and the position of women within it.

These developments were also arguably conditioned by the experience of the civil wars, insofar as the familial entanglements and especially the breakdown of marriage alliances among the leading combatants received special prominence in the common historical understanding of these conflicts. It was a generally accepted premise that the unravelling of the first triumvirate began not with the death of Crassus at Carrhae in 53 BCE, but in the previous year with the death of Pompey's wife (and Caesar's daughter) Julia, who was regarded as an essential moderating link between the two men (Vell. Pat., 2.47.2, Luc., B.C. 1.111-120). ${ }^{8}$ Octavian and Antony's relationship similarly hinged, or so the sources suggest, on a sequence of unsuccessful marriage alliances. The climax of the Perusine war was marked by Octavian's divorce from Fulvia's young daughter Clodia (Suet., Aug. 62.1, Dio, 48.5.2), just as the battle of Actium was preceded by Antony's rejection of his rival's sister Octavia (Liv., Per. 132, Dio, 50.3.2).

By reframing the crisis of civil war as a matter of domestic rather than civic turbulence, these narratives reveal how the metaphorical relationship between these two domains had begun to collapse in on itself as everything depended upon the personality of a few powerful principes. With the emergence of the domus Augusta as the sole locus

\footnotetext{
${ }^{8}$ See Ambühl in this volume.
} 
of power, the integrity of the family was no longer simply a metaphor for that of the civic community: the two had converged into a single institution. Thereafter, the situation became the one we find documented in Tacitus' Annals and Suetonius' biographies, in which dynastic politics were the only politics that mattered. 


\section{References}

Alexander, J. C. (2012), Trauma: A Social Theory. Malden, MA: Polity Press.

Alföldi, A. (1971), Der Vater des Vaterlandes im römischen Denken. Darmstadt:

Wissenschaftliche Buchgesellschaft.

Ash, R. (2007), Tacitus, Histories Book II. Cambridge: Cambridge University Press.

Beltrami, L. (1998), Il Sangue degli antenati: Stirpe, adulterio e figli senza padre nella cultura romana. Bari: Edipuglia.

Braund, S. M. (1992), Lucan: Civil War. New York: Oxford University Press.

Dixon, S. (1984), 'Infirmitas sexus: Womanly Weakness in Roman Law', Tijdschrift voor Rechtsgeschiedenis 52: 343-371.

Fantham, E. (1992), Lucan, De bello civili. Book II. Cambridge: Cambridge University Press.

Fantham, E. (2006), Julia Augusti: The Emperor's daughter. London: Routledge.

Fehrle, R. (1983), Cato Uticensis. Darmstadt: Wissenschaftliche Buchgesellschaft.

Flory, M. (1988), 'Abducta Neroni uxor: The Historiographical Tradition on the Marriage of Octavian and Livia." TAPA 118: 343-359.

Gabba, E. (1956), Appiano e la storia delle guerre civili. Florence: La Nuova Italia.

Galinsky, K. (1996), Augustan Culture: An Interpretative Introduction. Princeton: Princeton University Press.

Gordon, A. E. (1977), 'Who's Who in the Laudatio Turiae', Epigraphica 39: 7-12.

Gowing, A. M. (1992), The Triumviral Narratives of Appian and Cassius Dio. Ann Arbor: University of Michigan Press. 
Harich, H. (1990), 'Catonis Marcia: Stoisches Kolorit eines Frauenporträts bei Lucan (II 326-350)', Gymnasium 97: 212-223.

Hartmann, S. M. 1982. The Homefront and Beyond: American Women in the 1940's. Boston: Twayne Publishers.

Hau, L. I. (2016), Moral History from Herodotus to Diodorus Siculus. Edinburgh: Edinburgh University Press.

Hinard, F. (1990), 'Solidarités familiales et ruptures à l'époque des guerres civiles et de la proscription', in J. Andreau and H. Bruhns (eds.), Parenté et stratégies familiales dans l'antiquité romaine, 555-570. Rome: École Française de Rome.

Hunter, A. (1905), Johnny Reb and Billy Yank. New York: Neale Publishing Company. Lincoln, A. (1989), Speeches and Writings 1832-1858. Edited by R. P. Basler. New York: Library of America.

May, E. T. (2008), Homeward Bound: American Families in the Cold War Era. 2nd revised edn. New York: Basic Books.

McCubbin, H. I. and Patterson, J. M. (1982), 'Family Adaptation to Crises', in H. I. McCubbin, A. E. Cauble, and J. M. Patterson (eds.), Family, Stress, Coping, and Social Support, 26-47. Springfield: Charles C. Thomas.

McGinn, T. (2003), Prostitution, Sexuality, and the Law in Ancient Rome, 2nd edn. Oxford: Oxford University Press.

Miles, G. B. (1992), 'The First Roman Marriage and the Theft of the Sabine Women', in R. Hexter and D. Selden (eds.), Innovations of Antiquity, 161-196. New York: Routledge. 
Mommsen, T. (1905), Gesammelte Schriften, Vol. 1. Berlin: Weidmannsche Buchhandlung.

Osgood, J. (2006), Caesar's Legacy: Civil War and the Emergence of the Roman Empire. Cambridge: Cambridge University Press.

Osgood, J. (2014), Turia: A Roman Woman's Civil War. Oxford: Oxford University Press.

Panoussi, V. (2007), 'Threat and Hope: Women's Rituals and Civil War in Roman Epic', in M. Parca and A. Tzanetou (eds.), Finding Persephone: Women's Rituals in the Ancient Mediterranean, 114-134. Bloomington: Indiana University Press.

Purcell, N. (1986), 'Livia and the Womanhood of Rome', PCPS n.s. 32: 78-105.

Roller, M. B. (2001), Constructing Autocracy: Aristocrats and Emperors in JulioClaudian Rome. Princeton: Princeton University Press.

Sannicandro, L. (2007), 'Per uno studio sulle donne della Pharsalia: Marcia Catonis', MH 64: 83-99.

Schröder, B.-J. (2012), 'Römische “pietas”: kein universelles Postulat', Gymnasium 119: $335-358$.

Severy, B. (2003), Augustus and the Family at the Birth of the Roman Empire. New York: Routledge.

Syme, R. (1958), Tacitus. Oxford: Oxford University Press.

Treggiari, S. (1991), Roman Marriage: Iusti Coniuges from the Time of Cicero to the Time of Ulpian. Oxford: Oxford University Press.

Veyne, P. (1978), 'La famille et l'amour sous le haut-empire romain', Annales E.S.C. 33: $35-63$. 
